\title{
Chapter 11 \\ Where Water Meets Agriculture: \\ The Ambivalent Role of Water Users Associations
}

\author{
Timothy Moss and Ahmad Hamidov
}

\begin{abstract}
This chapter investigates the role of water users associations (WUAs) in managing the Fergana Valley's irrigation system at a local level. WUAs were established in the Uzbek section of the Fergana Valley only from the early 2000s onwards and are generally not regarded as having been effective to date, although individual instances of modestly successful WUAs indicate their future potential as viable entities for collective modes of water management. This chapter begins by explaining the origins, purpose and structure of WUAs in the Fergana Valley as set out in policy guidelines and then contrasts this with a study of how they are working in practice. In the concluding section, the effectiveness of WUAs in the Uzbek section of the Fergana Valley is assessed in terms of criteria derived from the literature. This chapter reveals that Uzbekistan's WUAs lack the funding, water user representation and resources to tackle the major structural problems confronting Fergana Valley's post-socialist irrigation system. Their heavy dependence on powerful institutional regimes for irrigation and for agriculture also severely restricts their action. There exist important exceptions, where WUAs are exploring innovative ways of coping with the enormity of their tasks, in isolation and in collaboration, but these represent only a small minority of WUAs in the region and are, to a large extent, dependent on temporary donor funding.
\end{abstract}

Keywords Water users associations $\bullet$ Water governance $\bullet$ Institutions $\bullet$ Path dependency $\bullet$ Transformation $\bullet$ Fergana Valley $\bullet$ Integrated water resources management - Participation • Irrigation • Education

\footnotetext{
T. Moss $(\bowtie)$

Leibniz Institute for Regional Development and Structural Planning (IRS),

Flakenstraße 28-31, 15537 Erkner, Germany

e-mail: MossT@irs-net.de

\author{
A. Hamidov \\ Department of Agricultural Economics, Humboldt-Universität zu Berlin,
}

Philippstraße 13, 10099 Berlin, Germany
} 


\subsection{WUAs in the Global Discourse on Integrated Water Resources Management}

Over the past century, the world has witnessed an almost threefold increase in the total area of irrigated agriculture (Ostrom 1992). Representing $20 \%$ of total cropland, irrigated agriculture produces more than $40 \%$ of the world's total agricultural output (Perry 2007, p. 369). Expansion of irrigated agricultural areas has been a key component of nation-building processes (Kreutzmann 2015, in this volume) and, in recent decades, the construction and modernisation of large-scale irrigation facilities has become the target of massive investment programmes of international donor agencies in developing and transition countries. However, towards the late twentieth century, the management and operation of irrigation systems, particularly at the community level, proved an increasing fiscal burden for many governments. As central government funds in many countries were reduced, maintenance standards declined and irrigation infrastructure began to deteriorate at a serious rate (World Bank 2007). One of the main solutions widely voiced from the early 1990s onwards has been the creation of so-called water users associations (WUAs), in which farmers are given more responsibility to manage and maintain local irrigation systems themselves.

WUAs have been defined as "a voluntary, nongovernmental, non-profit entity established and managed by groups of farmers located along one or several watercourse canals" (Winrock International 2007, cited in Gunchinmaa and Yakubov 2010, p. 166). Ideally, WUAs are set up by a group of farmers and other water users along one or more hydrological subsystems or watercourses to collectively manage, operate, maintain and develop a local irrigation and drainage system. Membership is based on contracts and/or agreements between the members and the WUA. In accordance with WUA by-laws, their main responsibilities generally include:

- Ensuring reliable distribution of water amongst water users

- Determining and collecting irrigation service fees

- Resolving disputes on water use and management of the irrigation system in an appropriate, transparent and democratic manner

- Maintaining, refurbishing and improving the irrigation system in the WUA operational area

Within the global debate on water resources management, the wide appeal of WUAs can be attributed not merely to the inherent advantages emanating from the self-organisation of local irrigation infrastructures by the farmers that use them but also to the various ways in which WUAs - on paper at least - play to the dominant discursive paradigm of integrated water resources management (IWRM) (for a definition of IWRM, see GWP 2000, p. 22). Within the global discourse on IWRM, increasing the involvement and responsibility of water users in water management issues has become a central tenet for successful implementation. Decentralising decision-making powers and strengthening the role of local water users is also acknowledged as a core element of IWRM in Central Asia and post-socialist 
transition countries in general (Dombrowsky et al. 2011; Dukhovny et al. 2013). Globally, WUAs are projected to play a critical role in promoting IWRM reform at the community level.

Whilst the aspirations for WUAs are high, it is now recognised that, to be successful, they are hugely dependent on favourable conditions. On the basis of past experiences worldwide, Merrey (1996, p. 4, also cited in Gunchinmaa and Yakubov 2010, p. 168) cites four principles as preconditions for an effective WUA. These are (1) a supportive institutional environment, (2) the capacity to operate and maintain infrastructure, (3) the benefits of user participation exceeding the costs and (4) effective collective choice arrangements. We will use these four principles to assess the performance of the Fergana Valley WUAs in Sect. 11.4.

Experiences from around the world indicate that some WUAs do live up to the aspirations placed in them and benefit from favourable institutional frameworks, at least in part. Frequently cited instances of largely successful WUAs include those created in Mexico in response to the economic crisis of the late 1980s, when responsibility for local irrigation management and infrastructure was transferred to water users (Rap and Wester 2013). In Turkey, WUAs were set up as part of a national decentralisation policy in response to the inability of the State Hydraulic Works (DSI) to continue funding the operation and maintenance of irrigation infrastructure (Uysal and Atis 2010). In Nepal, experience indicates that farmers with long-term irrigation management traditions can, through the development of autonomous and self-governing WUAs, improve communication, develop their own agreements, regulate compliance and sanction those who do not comply with their own rules (Ostrom 2000, p. 4). Such groups were able to distribute water equitably and keep their irrigation systems better maintained than those systems run by central government agencies $(\mathrm{ibid})$. These examples corroborate the expectations placed in WUAs to enable people within a community to pool their resources (e.g. knowledge, expertise and money), to allocate water more effectively amongst members, to keep irrigation and drainage infrastructure in a good condition, to resolve water-related disputes and to impose sanction mechanisms against noncontributors or rulebreaking individuals.

Many other examples from around the world, however, present a very different story of failure and conflict. The difficulties encountered in setting up and operating WUAs are manifold and include financial, political, institutional and administrative constraints. The driving forces for establishing WUAs differ hugely from country to country, depending on political and economic circumstances (World Bank 2007). In most places, the development of WUAs was promoted either through government programmes or by external donor-funded investment projects. These reforms often disregarded local knowledge and experiences. Instead, policies drew on blueprint models with little consideration for the specific sociopolitical context of a country and its institutional capacities. Moreover, implementation mostly followed a topdown bureaucratic approach, allowing little space for the active involvement of civil society (Theesfeld 2005; Yalcin and Mollinga 2007; Abdullaev et al. 2010).

A closer review of the literature on post-socialist countries shows that the strong push of the World Bank and other donor agencies to establish WUAs in communities 
neither provided for functional local irrigation sector management nor involved local water users in their creation (Theesfeld 2005). As a result, many WUAs (e.g. in Bulgaria) terminated after one irrigation season (ibid). Sehring (2009) reports that newly established WUAs in post-socialist Kyrgyzstan and Tajikistan are undermined by informal practices such as patronage and unauthorised water withdrawal. If the WUAs' tasks are to deliver water to its members in due time, keep irrigation and drainage canals maintained, punish those who do not comply with rules and resolve conflicts within the WUA, they were barely effective on the ground (ibid). Instead, when the head of the WUA was a local patron, he/she was in most cases able to ensure compliance with water rules using the authority of his position (Sehring 2009). Despite Central Asian governments issuing decrees on the establishment of WUAs and creating thousands of WUAs within a very short period of time, in reality most of them exist on paper only (Wegerich 2009; Abdullaev et al. 2010). Consequently, many commentators see WUAs in Central Asia as inactive and not financially viable (Wegerich 2000; Abdullaev et al. 2010). A low level of user participation and frequent external interventions into WUA internal procedures are additional constraints for WUAs' malfunctioning in Central Asia (Schlüter et al. 2010). In the following section, we take a closer look first at the origin and purpose of WUAs in the Fergana Valley (Sect. 11.2) and then study how they are working in practice (Sect. 11.3) before assessing their effectiveness in terms of the criteria listed above (Sect. 11.4).

\subsection{WUAs as Building Blocks of Irrigation Management in the Fergana Valley}

The emergence and practice of WUAs in the Fergana Valley cannot be understood without appreciating the history of irrigation management in the region. The chapter by Hermann Kreutzmann, analysing the trajectory of large-scale irrigation from Tsarist times to the present day, provides the necessary insight into the economic, political and sociocultural factors which have shaped this major water engineering project (Kreutzmann 2015, in this volume). In our chapter, we recollect three key factors of Fergana's irrigation system: its strong path dependency in both material and social terms, the powerful interdependence of water management and agricultural production and the conflictual nature of transboundary cooperation between today's independent post-socialist republics.

\subsubsection{Early Origins of WUAs}

In the Fergana Valley, WUAs were first established in the mid-1990s in Kyrgyzstan (Sehring 2009) but only in the early 2000s in Tajikistan (ibid) and in Uzbekistan (Hamidov 2007; Abdullaev et al. 2009). In all instances, the driving forces behind 
these reforms included the deterioration of on-farm water infrastructure, unequal distribution of water, frequent conflicts amongst water users, inefficient irrigation methods and significant reduction of the state budget for local irrigation administration. In the case of Uzbekistan, for example, during 1991-2000, there was a serious deterioration of the secondary and tertiary canal systems because former collective and state farms could not operate and maintain irrigation canals due to inadequate funding. This resulted in low yields and, subsequently, low incomes for farmers. Meanwhile, the distribution of irrigation water became severely unequal, especially for downstream farmers. Disputes amongst farmers over water increased. It became important to introduce farmer-based organisations in place of the poorly functioning collective farms. In 1996, the Ministry of Agriculture and Water Resources (MAWR) of Uzbekistan contracted the Irrigation and Water Problems Research Institute (former SANIIRI) to study the experience of different countries with WUAs and to set up a framework for the establishment of WUAs. In 1999, SANIIRI completed the study and presented its recommendations to MAWR. As a result, the first WUA was created in Uzbekistan in February 2000 in the Khorezm Region (Hamidov 2007). The first WUAs in the Uzbek section of the Fergana Valley were founded in January 2002 (MAWR RUz 2014).

Critical behind the emergence of WUAs was the IWRM Fergana project funded by the Swiss Agency for Development and Cooperation from 2001 onwards. This transboundary project helped institutionalise IWRM as the guiding policy paradigm for the region (Gunchinmaa and Yakubov 2010, p. 166; Dukhovny et al. 2013). A key element of this IWRM-inspired reform process was to transfer operation and maintenance responsibilities for on-farm irrigation to water users in the form of WUAs. This new governance structure at the lower level was, in theory at least, intended to encourage local farmers to act collectively in managing and maintaining their irrigation systems. Additional institutional arrangements, such as the irrigation service fee, were also introduced by this reform.

\subsubsection{Organisational Structure of WUAs}

Unlike in neighbouring Kyrgyzstan and Tajikistan, there is no specific law on WUAs in Uzbekistan (Gunchinmaa and Yakubov 2010, p. 173). The legal basis for their status and organisation is provided primarily by the Cabinet of Ministers' Decree No.8, approved in 2002, which determines WUAs as the entity responsible for irrigation management at on-farm level in Uzbekistan. Subsequently, the reformed national Water and Water Use Act of 29 December 2009 clarified the role of WUAs, specifying for instance that WUAs are required to deal with internal conflicts relating to water distribution amongst water users (Art. 2.1) and that they should cooperate with state agencies in protecting and conserving water (Art. 10). National policy guidelines require WUAs to be organised around two units: a decision-making body and a management body (ADB 2006). Figure 11.1 provides an example of the typical structure of a WUA in Uzbekistan. The upper 


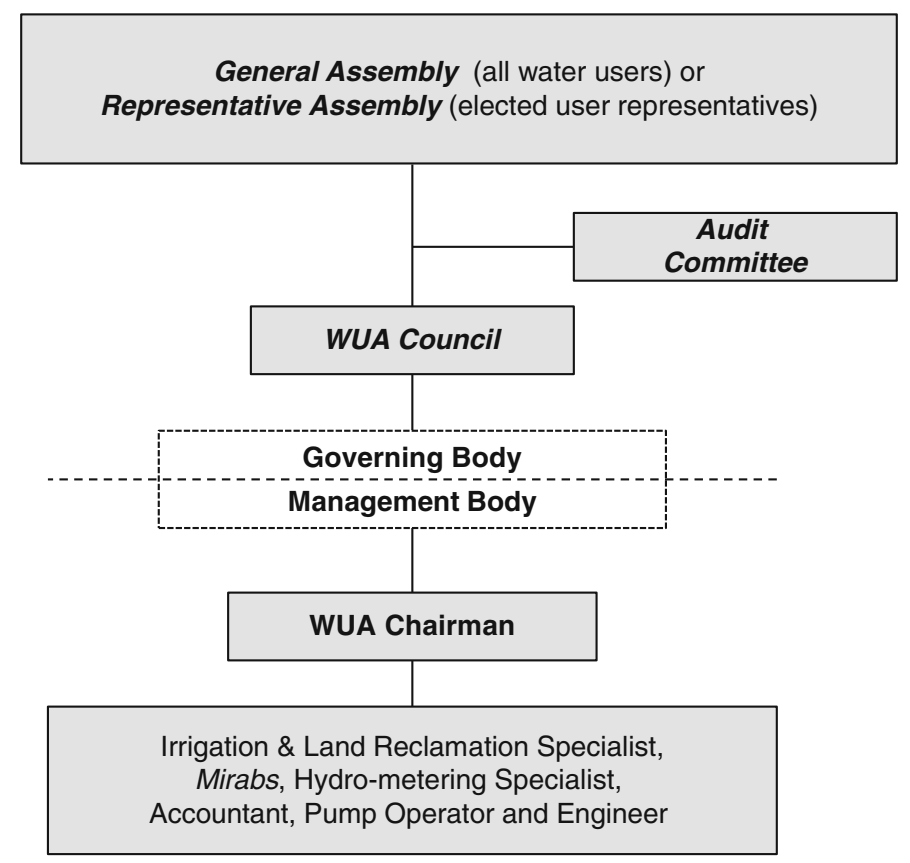

Fig. 11.1 Internal structure of a typical WUA in Uzbekistan (Source: ADB 2006)

part of the hierarchy comprises the general assembly, the WUA council and the audit committee; the lower part comprises the management team of chairman and specialist staff.

The supreme governing body of the WUA is the general assembly. The policy guideline specifies that the assembly should meet twice a year, when all members of the WUA are invited and encouraged to participate. When a member is unable to attend, he/she assigns a representative (usually a neighbouring farmer in the same WUA) to report on key messages emerging from the meeting. The main topics of discussion include electing a chairman, determining irrigation service fees (ISFs), evaluating the performance of the WUA management team and identifying the dates for maintaining on-farm irrigation canals through khashars, voluntary action of groups of people living in the community. In her study, Zavgorodnyay (2006) points to the fact that, in practice, the general assembly does not play a major role in the decision-making process. Instead, the chairman closely collaborates with the director of local machinery tractor parks (which provide agricultural machinery services to WUA members) and the head of the village citizens' assembly to reach decisions (ibid).

The primary task of a WUA council is to supervise and monitor the financial and technical activities of the WUA. Members of the WUA council work without salaries and are required to meet at least once a month. Typically, a WUA council has about five members elected by the assembly. The task of the audit committee is to 
conduct an annual review of all financial records and bank transfers of the WUA. The committee members are elected during the general assembly meeting and they report directly to the assembly. A WUA accountant assists the committee during the assessment.

Additionally, there is a WUA management team to manage a WUA's activity on a daily basis. This team includes the WUA manager, elected by the general assembly, an accountant and technical staff (e.g. mirab - or "water master" - and engineers), with its activities paid for through ISFs. The manager's responsibility is to handle irrigation-related activities in the WUA territory, identify potential irrigation canals to be maintained and initiate khashars, prepare the annual budget of the WUA and calculate irrigation service fees (ISFs) for both members (farmers) and non-members (e.g. local households). The WUA accountant is responsible for the overall financial activities of the association. He/she is in charge of collecting ISFs.

\subsubsection{Spatial Reform of WUAs}

A major reform to WUAs in Uzbekistan subsequent to their creation in the early 2000s was their spatial reorganisation around hydrographic, rather than administrative, units in accordance with IWRM principles (Dukhovny et al. 2013, p. 184; see Chap. 8, Moss and Dobner 2015, in this volume). With Decree No. 320 of the Cabinet of Ministers of July 2003 on "improving the organisation of water resources management", the Uzbek state started reforming its water sector based on a policy of decentralisation. A key element of this reform was to create a basin irrigation systems authority (BISA) in place of the former regional water resources management department (OblVodKhoz) and to establish irrigation systems authorities (ISAs) as well as main canal authorities (MCA), subordinated to BISA, in place of district water resources management departments (RayVodKhoz). As a result, the number of local water organisations was reduced. For example, 12 administrative organisations at provincial level were replaced by 10 BISAs in 2003. In the Fergana Valley within Uzbekistan, which includes three provinces (Andijan, Fergana and Namangan), three BISAs were created: Naryn-Karadarya, Naryn-Syrdarya and Syrdarya-Soh. Furthermore, 13 ISAs and 5 CMOs were also established as a result of the 2003 decree.

At the lower level of the water management hierarchy, this decree called for reorganising WUAs spatially around the local canal network, rather than administrative territories. Wegerich (2009) points out that at the WUA level the shift did not incorporate the drainage system but focused solely on the infrastructure delivery system. Since this reform, equity in the allocation of water supply per hectare has increased within the Khorezm province, the lower part of the Amudarya basin (ibid). Dukhovny et al. (2013) also report that the transition to the hydrographic principle in the Fergana Valley of Uzbekistan brought positive outcomes in terms of water distribution equity between up- and downstream communities. However, they also acknowledge that the transition to hydrographic units of management is not yet complete in the Fergana Valley as a whole (ibid). 
Table 11.1 Distribution of the number of WUAs in the Uzbek section of the Fergana Valley

\begin{tabular}{l|l|l|l}
\hline Provinces & No. of WUAs & No. of members & Total irrigated area (ha) \\
\hline Andijan & 109 & 6390 & 246,278 \\
\hline Fergana & 124 & 6098 & 322,167 \\
\hline Namangan & 147 & 5793 & 273,104 \\
\hline
\end{tabular}

Source: MAWR RUz (2014)

\subsubsection{Current Status of WUAs}

By the end of 2013, 1510 WUAs had been established in Uzbekistan, serving nearly 57,000 individual farmers and covering about 4.2 million ha (MAWR RUz 2014). Within the Fergana Valley, comprising three provinces of Uzbekistan, the total number of WUAs is 380. On average, each WUA covers about 2200 ha, varying significantly between different provinces (see Table 11.1). As a result of the state's land consolidation policies of 2008, 2009 and 2010 (Moss and Dobner 2015, in this volume), the number of members representing each WUA in the valley has sharply declined and, on average, each WUA has now about 50 members. According to data from MAWR RUz (2014), despite the fact that WUAs were initially created from the beginning of the 2000s in the Fergana Valley, most associations were re-established based on hydrographic principles and reregistered at the Ministry of Justice as a non-governmental and non-profit organisation only in the late 2000 s.

\subsection{Fergana Valley's WUAs in Practice}

Created by central government decree yet without a clear regulatory mandate or financial support, the WUAs in Uzbekistan have faced from the beginning an uphill struggle. On paper, they are an integral piece in the hierarchical jigsaw of Uzbek water management, filling the institutional void for on-farm irrigation systems left by the collapse of collective farms. Expectations in their performance were - and still are - high, although for a variety of reasons. State water authorities want WUAs to keep the existing irrigation system going, donor organisations hope WUAs can generate more participatory forms of integrated water resources management, and farmers want WUAs to provide them with the water they need for an increasing variety of crops. Caught between these multiple claims in a context of severe socioeconomic transformation and deep-seated authoritarian rule, WUAs face an unenviable task. How, then, are they working in practice? To what extent are they fulfilling the expectations placed in them? How far do they meet the principles of success as defined in the international literature on WUAs?

Taking the Uzbek section of the Fergana Valley as our case study area (see Fig. 11.2), we investigate in this section past and current experiences of WUAs working at the interface of water management and agricultural production on the 


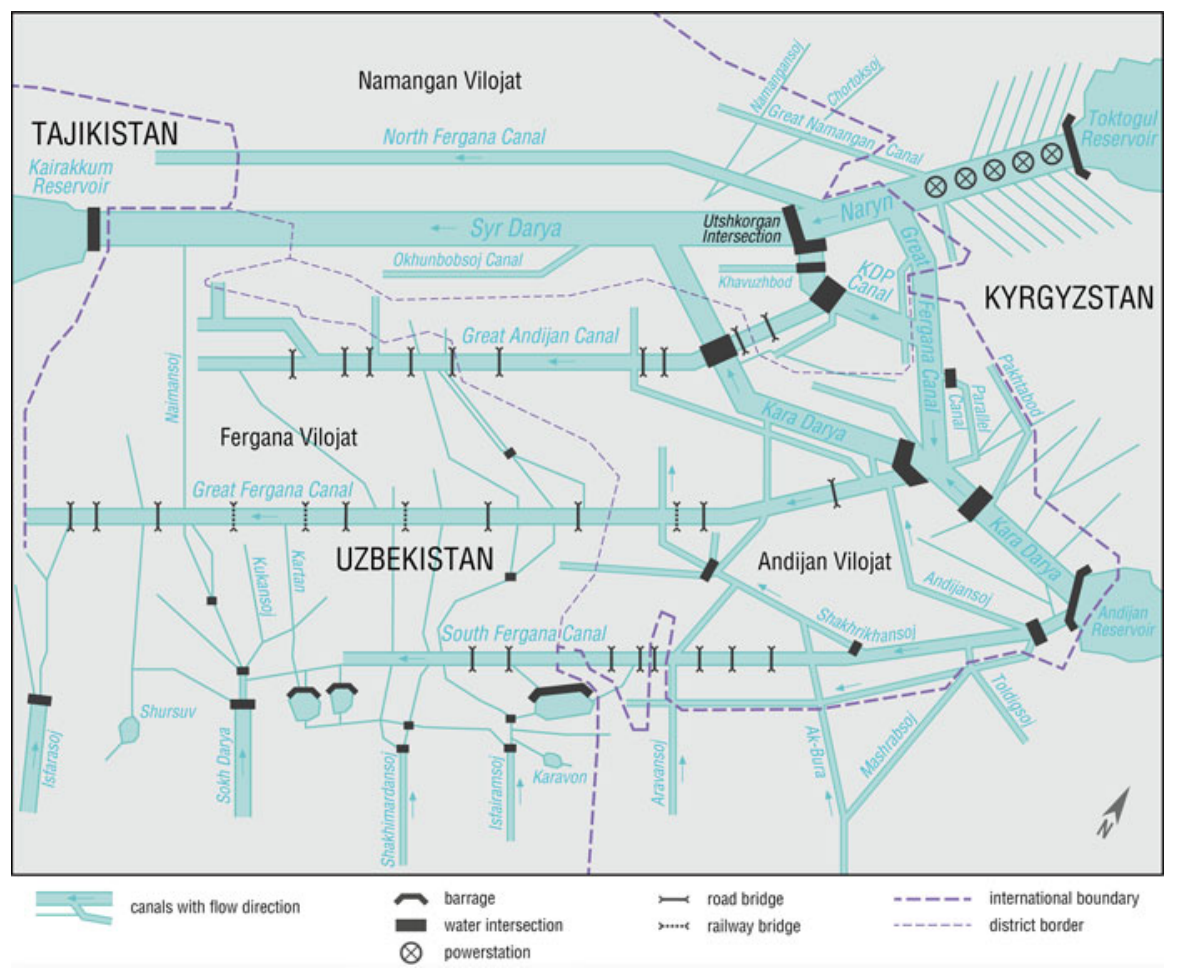

Fig. 11.2 Stylised map of the Main Canals in the Uzbek section of the Fergana Valley (Source: H. Kreutzmann 2015 in this volume pp. 113-127)

farm level. We are interested in revealing how water policy and regulations get translated into irrigation management practices on the ground and what informal "rules in use" (Ostrom 1990) are emerging in response. To this end, we have analysed the literature on WUAs in the Fergana Valley - in particular studies emerging from the IWRM Fergana Valley project funded by the Swiss Agency for Development and Cooperation - and field notes taken during a study trip visiting various WUAs and irrigation authorities in the region in May 2014. The section explores four practices pertinent to the role of WUAs: practices of representation, leadership, regulation and education.

\subsubsection{Practices of Representation}

The potential value of WUAs - following the global discourse on IWRM - lies in them providing an institutional basis for water users in an irrigation area to manage available water resources more effectively and equitably through collective action. 
This depends on the active participation of the farmers using irrigated water in decision-making processes and management practices of WUAs. The ways in which water users are represented in WUAs are, thus, of critical importance. In Uzbekistan, the top-down, technocratic nature by which WUAs were created in the early 2000s set the pattern for the hierarchical and largely unrepresentative design of WUAs in the Fergana Valley and elsewhere. Although a prime task of WUAs is to resolve disputes over water allocation, requiring close collaboration with farmers, water users themselves were neither consulted nor informed about the creation of the WUAs and the reorganisation of water management this implied. "Therefore the water users considered the WUAs as another water administration imposed on them, and not a way of introducing collective action water management" (Abdullaev et al. 2010, p. 1035).

Representation of water users within WUAs is generally very weak (Dukhovny et al. 2008). Council members of WUAs are elected from amongst the water users of the irrigation area served, but they are not active in the decision-making process. Most WUA councils are ineffective, leaving authority in the hands of the management body of paid officials and, in particular, the WUA chairman. The influence of individual farmers is limited, as a rule, to the annual general assembly of the WUA, a platform for the WUA management to inform members rather than a forum for open debate (WUA Tomchikul). The old Soviet-style command system tends to stifle participatory forms of governance (Gunchinmaa and Yakubov 2010). Noting also the effects of limited funding, Schlüter et al. conclude from their research that:

WUAs in Uzbekistan have in reality a poor decision-making mandate, are strongly influenced by patronage networks and interventions of the khokims (local governors) into their internal processes and suffer from a lack of financial means which all contributes to their malfunctioning. (Schlüter et al. 2010, p. 629)

In the Uzbek context, then, the term "water users association" is something of a misnomer. WUAs are de facto bodies set up by the government to secure state production targets for cotton and wheat by maintaining the existing irrigation system and ensuring the required allocation of water to the farmers. In short, WUAs in Uzbekistan may be acting on the behalf of water users but not at their behest.

One indictment of the ineffectiveness and unrepresentative nature of WUAs is the recent emergence in the Fergana Valley of water user groups (WUGs) as self-help initiatives organised by water users themselves (Dukhovny et al. 2008; Abdullaev et al. 2010). Here, farmers "have taken water management into their own hands", developing their own modes of collective action at the local level to manage water as a common pool resource (Abdullaev et al. 2010, p. 1031). Created by farmers themselves, the WUGs in the Fergana Valley have received financial support and advice from the IWRM project funded by the SDC and implemented by SIC-ICWC and IWMI. The number of WUGs in the South Fergana Canal area alone rose rapidly from 23 in 2006 to 160 in 2008 (Abdullaev et al. 2010, p. 1039). Some have emerged out of former collective farm brigades, some out of an extended family and others in response to a local water distribution conflict. WUGs not only own and maintain pumps and clean the smaller irrigation canals but they also introduce their own rules for water 
distribution and monitor water allocations, generating new levels of transparency to irrigation services (Abdullaev et al. 2010). They have no legal status but are proving increasingly influential as a voice for water users rights, drawing on the authority of informal institutions, social norms and local leaders (on informal institutions of irrigation in post-Soviet Central Asia, see Sehring 2009). The inclusion of WUG leaders in WUA councils is regarded by some commentators as a major step towards transforming WUAs into more participative, responsive organisations acting in water user interests (Abdullaev et al. 2010). These WUG leaders are raising the concerns of local farmers in the WUAs, demanding action and offering options for cooperative ventures. Their degree of influence depends heavily, however, on the willingness of the WUA chairman to share power.

A second attempt to improve representation in the South Fergana Canal area is the emergence of a Canal Water Users Union of South Fergana Canal in 2005, representing the first and only umbrella organisation for WUAs in any region in Uzbekistan. It was created with funding from the IWRM Fergana Valley project with the task of advising new WUAs and resolving conflicts within and between them over water allocation (Abdullaev et al. 2009). All 43 WUAs in the top two reaches of the South Fergana Canal are members of the union. It works primarily by inviting WUA representatives to its central office to discuss differences and is unusual in that its activities focus not on technical issues but on people and their interaction. Even though the project - together with its funding - has been terminated, the federation continues to operate, paying its seven staff members with fees collected from its member organisations. This, in itself, is an indication that the federation is regarded as providing a service of value to water users.

Issues of representation are by no means restricted to structures and procedures within and between WUAs but relate to higher levels of decision-making, where WUA interests need articulating. Referring to the representation of WUA leaders in councils and committees at subbasin and basin levels, Dukhovny et al. reflect:

Our experience shows that the management of WUAs and Canal Water User Committees do not participate enough in the processes of water resources planning, allocation, and management, as well as in decision making relating to maintaining and rehabilitating of water infrastructure and seeking funding sources. (Dukhovny et al. 2008, p. 28)

Within the IWRM pilot areas, there are positive signs that WUAs are being given a voice in the water councils of basins and subbasins and in the water committees of irrigations systems, but few water officials are prepared to view such forms of representation as beneficial to their own position (Dukhovny et al. 2008, p. 29).

\subsubsection{Practices of Leadership}

How WUAs are run is, in practice, highly dependent on the people in charge and their modes of leadership. The allocation of water via irrigation systems is traditionally the responsibility of the mirab or "water master". This practice has not changed 
with the emergence of WUAs. The mirab is the sole operator of the weirs, sluices and settings regulating the amount of water distributed to each farmer. He/she is the one who sanctions farmers that manipulate weirs to their advantage, imposing fines or a reduction in the water allocation. A WUA is heavily dependent on its chairman, who is occasionally the only person in full-time employment. This dependency on persons of authority is a product not only of a WUA's internal structure and staffing but also of a strong cultural reliance on hierarchical forms of rule in a community. In many WUAs, old elites remain figures of considerable influence. This raises the risk of patronage, clientelism and expected codes of conduct (Schlüter et al. 2010). Here lies the ambivalence of leadership in the Fergana Valley. Strong leadership of a WUA or WUG is needed to gain the respect and support of water users internally and water officials externally. The lack of leadership skills is widely regarded as a serious impediment to the performance of WUAs. However, strong leadership can be a vehicle for sustaining predominant power relations in a community at the expense of inclusive, collaborative modes of governance.

\subsubsection{Practices of Regulation}

On paper, the tasks of WUAs in regulating water flows via irrigation systems are straightforward. WUAs are expected to draw up a water use plan for their area, distribute water to their members according to this plan, monitor flow rates on irrigation and drainage canals, keep records of water use, repair and maintain irrigation and drainage systems and conduct land reclamation and drainage (Dukhovny et al. 2008). In practice, their ability to regulate water flows is severely constrained not only by limited resources but also by the stringent quotas set by higher authorities. The water use plan developed by the WUAs in a bottom-up process of data collection from the farmers on the basis of their water requirements for planned crops is frequently rendered redundant by the top-down practice of setting water use quotas by state bodies. These quotas emerge from the national Ministry of Agriculture and Water Resources and are then passed down the water management hierarchy, being translated into quotas for the Basin Irrigation Systems Authority, then for the Irrigation Systems Authority at district level and finally for the WUAs and the farmers they serve (Kenjabaev 2014, pp. 16, 26-27; see Fig. 11.3). Even this top-down allocation regime does not work as intended in practice. Inadequate monitoring and lack of staff make it difficult for WUAs to ensure adherence to the quotas for irrigated water at the field level. More fundamentally, there is a lack of incentive for most actors at the local level to adhere to the water-use limits. As Kenjabaev discovered in his research, "[...] neither WUAs nor farmers and other water users have an incentive to know the applied and delivered amount of water as no price is set for water in Uzbekistan" (Kenjabaev 2014, p. 27, footnote 6). The result is extensive non-compliance of the quotas set by the water authorities.

The problem is further complicated by the different modes of water regulation applied to cash crops on the one hand and household crops on the other. Whereas 


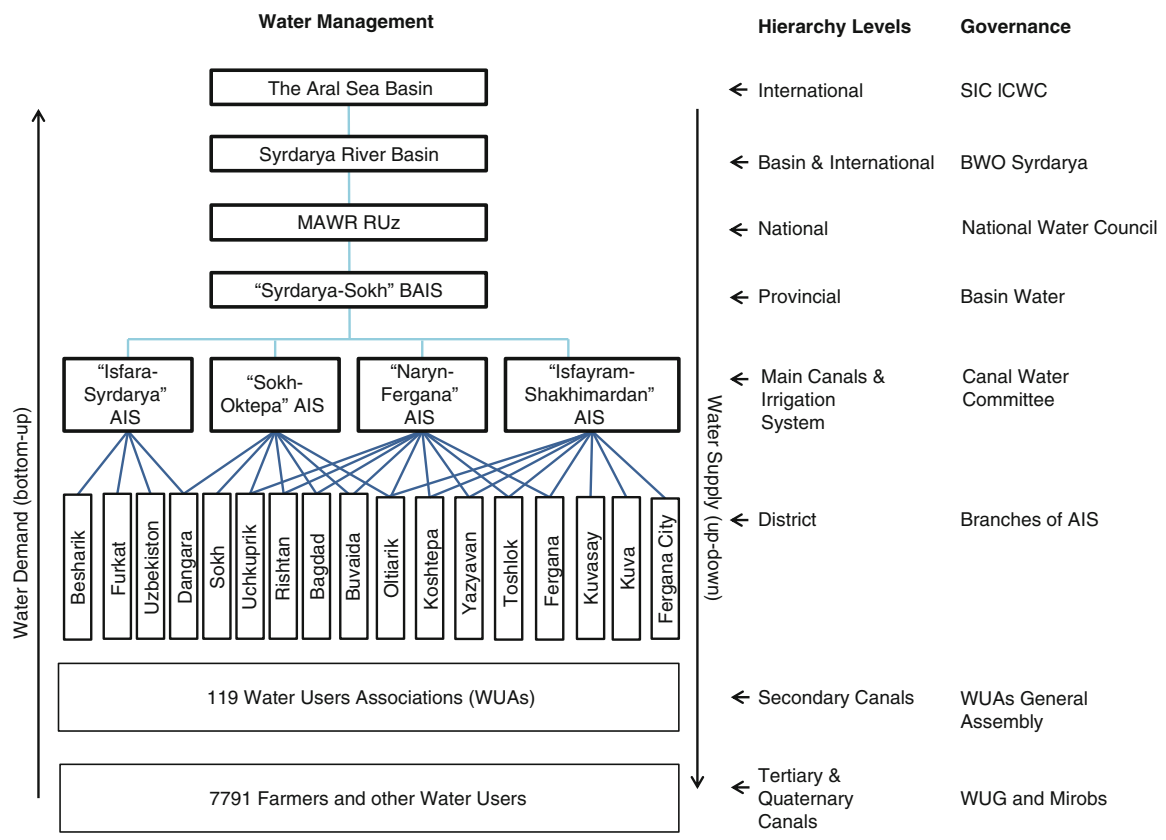

Fig. 11.3 Structure of water management organisations in Uzbekistan (Source: Kenjabaev 2014, p. 27)

water allocated for the compulsory crops of cotton and wheat is tightly regulated by the WUAs, enabling them to collect fees in return for services, for voluntary crops (such as fruit and vegetables) grown by individual households or small cooperatives of local residents, water is poorly regulated and rarely paid for. Here, again, there is emerging evidence of water users developing their own forms of collective action in response to an institutional void. In the WUA Kadyrjon-Azamjon, an unusual system of water management has developed whereby a community citizen council organises water allocation and cost collection itself.

Practices of regulation are, indeed, closely bound to practices of payment for irrigation services rendered. WUAs do not receive any state funding as a rule, although temporary subsidies can be made available from water management organisations for specific measures, such as the reduction of water losses. Also, in Uzbekistan, water fees are not levied, in line with the principle that water is a public good. Instead of charging for water used, WUAs are dependent on fees for the irrigation services they provide. These irrigation service fees were introduced in Uzbekistan only in 2001. They can vary according to the size of the farm and to the type of crop. For example, farmers in the WUA Tomchikul pay 45,000 soum ${ }^{1}$ per ha for (private) orchards but only 20,000 soum per ha for cotton fields (excursion in WUA Tomchikul). The incentives for farmers to conserve water are, under this system,

\footnotetext{
${ }^{1}$ Soum is the Uzbek currency. 1 Euro $\approx 3100$ UZS.
} 
minimal. Furthermore, the non-payment of fees for irrigation services is a major problem for almost all WUAs in the region, seriously limiting their scope for action and, thereby, undermining their effectiveness. An attempt in the mid-2000s in the Bukhara province to price water on a consumption, rather than a per-unit-of-area, basis failed for political reasons out of fear of protests by the WUA's members (interview with the Swiss Agency for Development and Cooperation). Experiences such as this reinforce a technical-managerial approach to the work of WUAs, in which engineering solutions are applied to what are essentially social problems. Under such circumstances, it is perhaps not surprising that ecological issues, relating either to local watercourses and water-based landscapes or the state of the entire river basin, are not addressed by WUAs at all.

\subsubsection{Practices of Education}

Several WUAs that are active - in particular those selected as pilots for IWRM projects - are offering training for their members on how to optimise irrigation practices. Faced with a large number of new farmers, following land reforms, with little or no experience of managing crops themselves, many WUAs pursue an educational mission. The WUAs provide information and expertise to their members in the form of events, brochures, experimental and demonstration sites and advice by agricultural advisors (see Fig. 11.4). Beyond technical knowledge, this educational programme is intended to encourage greater self-responsibility amongst farmers accustomed to relying on the state but also to promote greater willingness to pay the WUAs for the services they provide.

This educational mission does not stop at the boundaries of the WUAs but is a central feature of irrigation management in post-Soviet Uzbekistan in general and of the IWRM project in the Fergana Valley in particular. Substantive training programmes for irrigation managers are provided by the Central ICWC Training Centre in Tashkent, with branches in the provinces of Andijan, Fergana and Khodjent (see Fig. 11.5). Training schemes funded by the IWRM Fergana Valley project provide extension services at the level of BISAs, ISAs and WUAs, with the active support of the Swiss Agency for Development and Cooperation. They also target the creation of more WUGs in the Fergana Valley. The emphasis placed on scientific knowledge and its application in the field resonates powerfully with Soviet practices of training irrigation specialists and Soviet imagery of the heroic water engineer making barren lands fertile in the name of national modernisation.

Nevertheless, these educational schemes have a number of drawbacks. Firstly, their reliance on project-based funding makes their long-term sustainability questionable. Secondly, they focus largely on technical and managerial issues, offering little help to practitioners when it comes to dealing with disputes over water allocations, developing an appreciation of environmental impacts and constraints or exploring economic incentives for water conservation. What is lacking is a multidisciplinary, cross-sectoral and basin-oriented approach to irrigation training. In this 


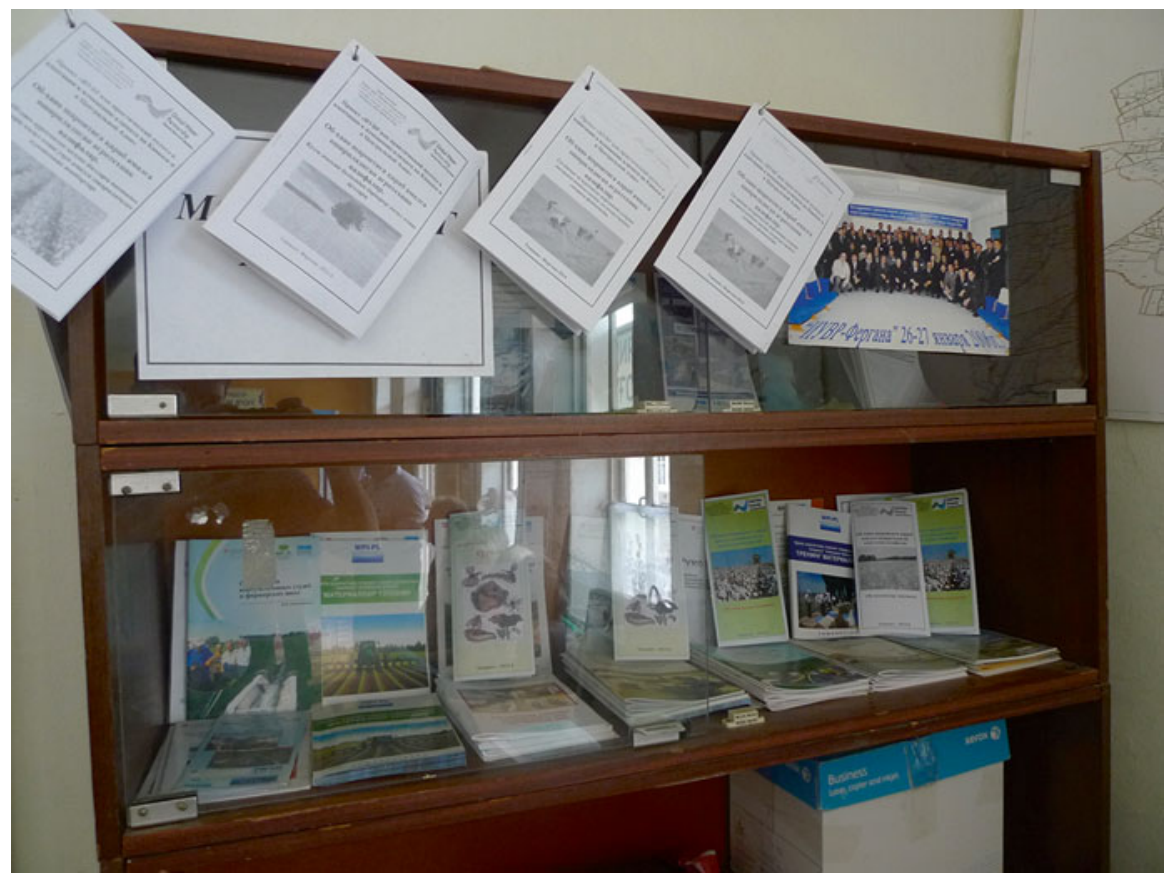

Fig. 11.4 Information and training material on irrigation practices at the WUA Kadyrjon-Azamjon (Photo: T. Moss)

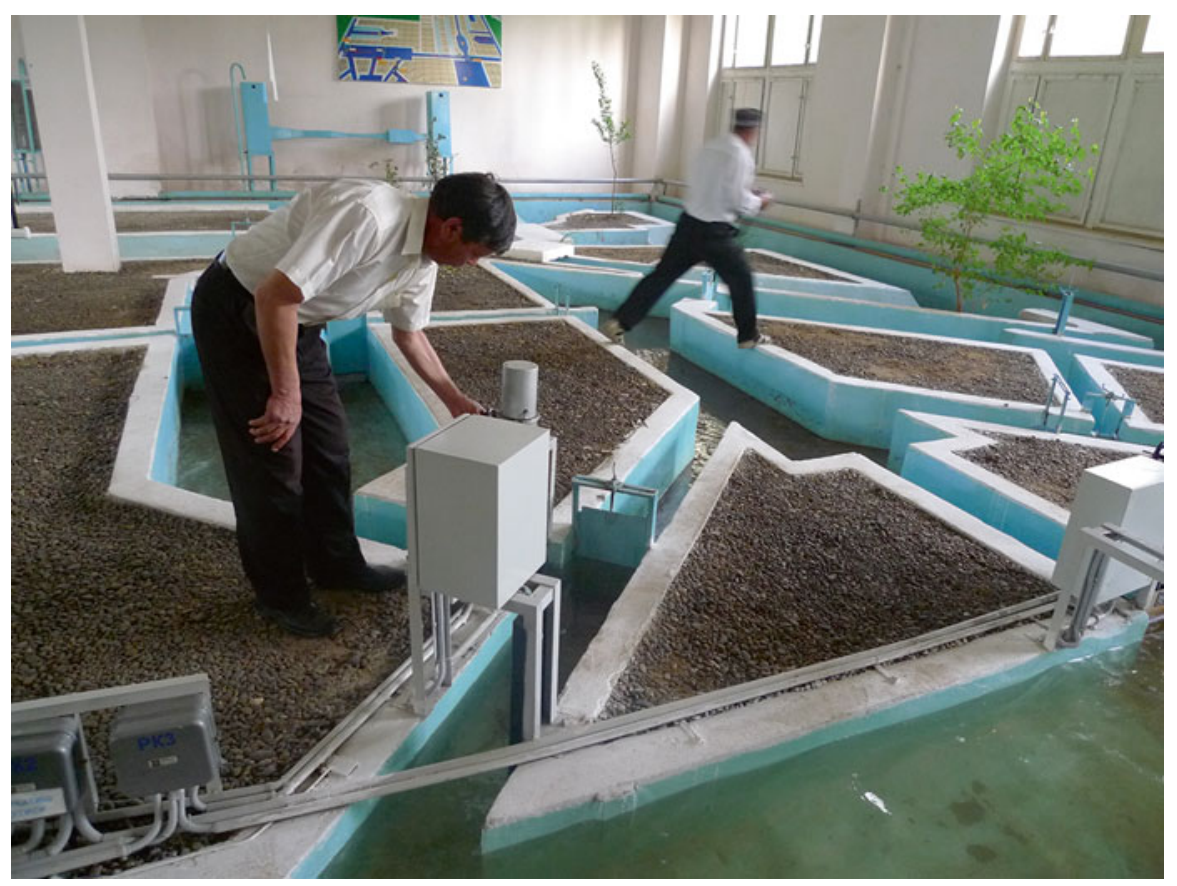

Fig. 11.5 A model irrigation scheme at the Marhamat Vocational College in Andijan (Photo: T. Moss) 


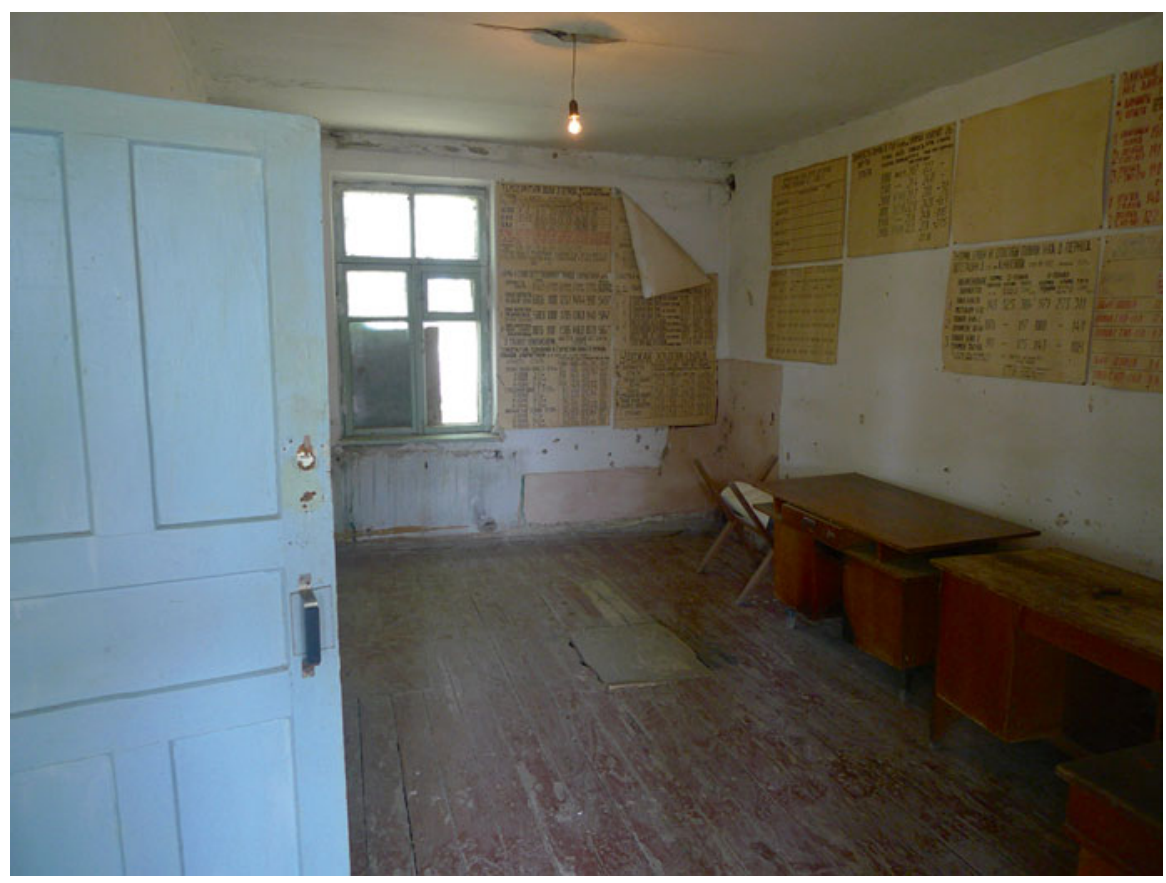

Fig. 11.6 The research station of SANIIRI: a shadow of its former self (Photo: T. Moss)

sense, the educational programmes on offer are struggling to find their way between a Soviet tradition reliant on huge amounts of technical data generated by large teams of specialised scientists on the one hand and modern requirements for different kinds of knowledge provided under the auspices of a much reduced budget for irrigation research on the other (see Fig. 11.6).

\subsection{WUAs as Models for Emulation?}

The experience of WUAs in the Uzbek section of the Fergana Valley - and not only there - is a sobering one. Whilst it is perhaps inevitable that the WUAs could never meet all the expectations made of them at their inception, their general lack of impact on irrigation services and water governance is indicative of deeper, structural weaknesses in water and land management. WUAs in Uzbekistan are, in essence, not really water users associations at all, in that they were created by central government decree, permit only minimal representation of water users and operate to satisfy state targets for cash crops in accordance with state quotas for water allocation. Thus they fail to meet the definition of WUAs given in Sect. 11.1. They also fail to fulfil any of Merrey's four principles for successful WUAs, also cited above. The 
institutional environment within which they operate is not supportive, providing for little funding whilst demanding a high degree of conformity (1). Their capacity to operate and maintain irrigation infrastructure is severely limited not only by a lack of money but also by an inability to mobilise support from water users (2). Many WUAs in the region are clearly not convinced that the benefits of water user participation outweigh the transaction costs involved (3). As a result, WUAs generally have proven unable to develop effective collective choice arrangements in managing water and water infrastructures (4). In terms of the first core challenge set out in Chap. 8, (Moss and Dobner 2015, in this volume) - relating to the water-land nexus - they are caught between two powerful institutional regimes, for irrigation and for agriculture, respectively, with each placing unrealistic and unsustainable demands on WUAs. Prospects for integrated rural development, taking a crosssectoral approach to the water-land-food nexus, are currently poor. The story of WUAs in the Fergana Valley is also a rich portrayal of the tensions emerging from parallel trends of path dependency and transformation - the second core challenge addressed in this part of the book. The legacy of the Soviet era lives on in many informal institutions and formal structures of irrigation management. At the same time, the WUAs are having to cope with enormous changes in the wake of postSoviet land reforms, transboundary relations and emergent modes of governance.

There are important exceptions to this negative picture, situations where WUAs are exploring innovative ways of coping with the enormity of their tasks, but they represent only a small minority of WUAs in the region and are, to a large extent, dependent on temporary donor funding. The rapid growth of WUGs is perhaps the most promising recent development in irrigation governance in the Fergana Valley, as it represents an emergent desire of farmers to make their own collective arrangements for water management. It is, however, too early to reach any judgement on how they are likely to work in the future and what impact they might have on the practices of WUAs. What current experiences of WUGs indicate is that strengthening the decision-making powers of water users can generate amongst them a greater sense of collective responsibility for managing water and land in a more sustainable way and that this can, in favourable circumstances, stimulate learning processes at the WUA level too. In terms of the future, this recent development would seem to resonate with what Lankford and Hepworth call the "bazaar" model of water management (2010). Rather than a "cathedral" model of hierarchical, monocentric rule, the authors suggest that a polycentric model (the "bazaar"), in which various organisational forms coexist, is especially suited to situations characterised by little reliable data, fluctual water supply and demand and under-resourced regulatory agencies - all factors prevalent in the Fergana Valley.

\section{Field Trips and Discussions}

1. Central Office of Fergana Irrigation District, Fergana, 4 May 2014

2. Office of South Fergana Canal Management, 5 May 2014

3. WUA Kadyrjon-Azamjon, 5 May 2014

4. Federation of WUAs of South Fergana subbasin, 5 May 2014

5. SANIIRI Research Station, 6 May 2014 
6. Automated irrigation management system, Uchkurgan, 7 May 2014

7. WUA Tomchikul, 7 May 2014

8. Marhamat Vocational College, Andijan, 7 May 2014

9. Swiss Agency for Development and Cooperation, 8 May 2014

Open Access This chapter is distributed under the terms of the Creative Commons Attribution Noncommercial License, which permits any noncommercial use, distribution, and reproduction in any medium, provided the original author(s) and source are credited.

\section{References}

Abdullaev I, Kazbekov J, Manthritilake H et al (2009) Participatory water management at the main canal: a case from South Ferghana canal in Uzbekistan. Agric Water Manag 96:317-329. doi:10.1016/j.agwat.2008.08.013

Abdullaev I, Kazbekov J, Manthritilake H et al (2010) Water user groups in Central Asia: emerging form of collective action in irrigation water management. Water Resour Manag 24:1029-1043. doi: $10.1007 / \mathrm{s} 11269-009-9484-4$

ADB (2006) Republic of Uzbekistan. Guidebooks for water users' associations in Uzbekistan. Technical assistance consultant's report. Asian Development Bank, Tashkent

Dombrowsky I, Horlemann L, Hagemann N (2011) Integrated water resources management in post-socalist countries - a comparison of Mongolia and Ukraine. Paper presented at the international conference on integrated water resources management, Dresden, 12-13 Oct

Dukhovny V, Sorokin A, Stulina G (2008) Should we think about adaptation to climate change in Central Asia? Adaptation to climate change: regional challenges in light of world experiences. Scientific Information Center of the Interstate Commission for Water Coordination (SIC ICWC), Tashkent

Dukhovny VA, Sokolov VI, Ziganshina DR (2013) Integrated water resources management in Central Asia, as a way of survival in conditions of water scarcity. Quat Int 311:181-188. doi:http://dx.doi.org/10.1016/j.quaint.2013.07.003

Gunchinmaa T, Yakubov M (2010) Institutions and transition: does a better institutional environment make water users associations more effective in Central Asia? Water Policy 12:165-185. doi:10.2166/wp.2009.047

GWP (2000) Integrated water resources management. Technical advisory committee, background paper no. 4. Global Water Partnership, Stockholm

Hamidov A (2007) Water user associations in Uzbekistan: review of conditions for sustainable development. Working Paper for the World Bank Institute (WBI). Washington, DC

Kenjabaev SM (2014) Ecohydrology in a changing environment. Dissertation, Justus-LiebigUniversität Gießen

Kreutzmann H (2015) From upscaling to rescaling - the Fergana Basin's transformation from Tsarist irrigation to water management for an independent Uzbekistan. In: Huettl RF, Bens O, Bismuth C, Hoechstetter S (eds) Society - water - technology: a critical appraisal of major water engineering projects. Springer, Dordrecht, pp 113-127

Lankford B, Hepworth N (2010) The cathedral and the bazaar: monocentric and polycentric river basin management. Water Altern 3:82-101

Merrey DJ (1996) Institutional design principles for accountability in large irrigation systems. International Irrigation Management Institute (IIMI), Colombo

Moss T, Dobner P (2015) Between multiple transformations and systemic path dependencies. In: Huettl RF, Bens O, Bismuth C, Hoechstetter S (eds) Society - water - technology: a critical appraisal of major water engineering projects. Springer, Dordrecht, pp 101-111

Ostrom E (1990) Governing the commons: the evolution of institutions for collective action. Cambridge University Press, Cambridge 
Ostrom E (1992) The rudiments of a theory of the origins, survival, and performance of commonproperty institutions. In: Bromley D (ed) Making the commons work: theory, practice, and policy. ICS Press, San Francisco, pp 293-318

Ostrom E (2000) Reformulating the commons. Swiss Polit Sci Rev 6:29-52. doi:10.1002/ j.1662-6370.2000.tb00285.x

Perry C (2007) Efficient irrigation; inefficient communication; flawed recommendations. Irrig Drain 56:367-378. doi:10.1002/ird.323

Rap E, Wester P (2013) The practices and politics of making policy: irrigation management transfer in Mexico. Water Altern 6:506-531

MAWR RUz (2014) Statistical report. Department of Water Resources Balance and Development of Water Saving Technologies. Ministry of Agriculture and Water Resources of the Republic of Uzbekistan, Tashkent, Uzbekistan

Schlüter M, Hirsch D, Pahl-Wostl C (2010) Coping with change: responses of the Uzbek water management regime to socio-economic transition and global change. Environ Sci Pol 13:620 636. doi:10.1016/j.envsci.2010.09.001

Sehring J (2009) Path dependencies and institutional bricolage in post-soviet water governance. Water Altern 2:61-81

Theesfeld I (2005) A common pool resource in transition. Determinants of institutional change for Bulgaria's postsocialist irrigation sector. Shaker, Aachen

Uysal ÖK, Atis E (2010) Assessing the performance of participatory irrigation management over time: a case study from Turkey. Agric Water Manag 97:1017-1025

Wegerich K (2000) Water user associations in Uzbekistan and Kyrgyzstan: study on conditions for sustainable development, Occasional paper no. 32. School for Oriental and African Studies, London

Wegerich K (2009) Shifting to hydrological boundaries - the politics of implementation in the lower Amu Darya Basin. Phys Chem Earth 34:279-288. doi:http://dx.doi.org/10.1016/j. pce.2008.06.003

Winrock International (2007) What is WUA? A guideline for Central Asia, Little Rock, AR

World Bank (2007) Global development of farmer water user associations (WUA): lessons from South-East Asia. World Bank Institute (WBI), Washington, DC

Yalcin R, Mollinga PP (2007) Water users associations in Uzbekistan: the introduction of a new institutional arrangement for local water management. Amu Darya case study - Uzbekistan. Center of Development Research, Bonn

Zavgorodnyay D (2006) Water user associations in the Republic of Uzbekistan. Theory and practice. Dissertation, Center of Development Research (ZEF), University of Bonn 